\title{
Acute epididymorchitis: a study of the predisposing factors and immediate management outcome in adult men in Irrua, Nigeria
}

This article was published in the following Dove Press journal:

Clinical Audit

I March 2016

Number of times this article has been viewed

\author{
Eshiobo Irekpita' \\ Friday Ogbetere' \\ Emmanuel Esezobor ${ }^{2}$ \\ 'Urology Division, Department of \\ Surgery, ${ }^{2}$ Department of Surgery, \\ Plastic Surgery Division, Irrua \\ Specialist Teaching Hospital, Irrua, \\ Nigeria
}

Aim: To assess the immediate (14 days) outcome of management and to determine the predisposing factors $(\mathrm{PF})$ to acute epididymorchitis in this rural community.

Materials and methods: This is a retrospective study. All men who were diagnosed as having acute epididymorchitis within the study period of 5 years were included. Those with epididymorchitis secondary to testicular tumors were excluded. Information related to age, HIV infection and other PF, organisms isolated, duration of hospital stay, antibiotic treatment, adjunct treatment, and duration of symptoms before presentation were documented. Immediate outcome was graded as good if symptoms and signs resolved within 2 weeks of treatment or poor if this took more than 2 weeks. Findings were analyzed using simple statistical methods and statistical package for the social sciences (SPSS-17).

Results: A total of 58 men met the selection criteria and were included in the study. The risk factors included two (3.4\%) prostatitis, $36(62.1 \%)$ bladder outlet obstruction, three $(5.2 \%)$ trauma/instrumentation, and ten (17.2\%) multiple sexual partners. No risk factor was documented in seven $(12.1 \%)$. One $(1.7 \%)$ of the men, who also had bladder outlet obstruction, was HIV positive. When age was cross tabulated with risk factors, there was a significant correlation $(P=0.000)$ but it had no significant effect on immediate management outcome $(P=0.442)$. Immediate outcome was considered good in $40(69 \%)$ and poor in $18(31 \%)$. Independent factors that affected outcome included the duration of symptoms before presentation $(P=0.000)$, presenting symptoms $(P=0.000)$, and the need for adjunct treatment $(P=0.018)$. Ciprofloxacin was the antibiotic used in 57 (98.28\%), while cefuroxime was used in one (1.7\%). These drugs had no statistically significant correlation with outcome.

Conclusion: Many patients with epididymorchitis have PF that need to be treated to avoid its recurrence and complications. It would then mean that the diagnosis "acute epididymorchitis" is incomplete without including the PF. In this study, ciprofloxacin was not uniformly effective $(69 \%)$ using the aforementioned criteria, indicating the need for prospective studies to identify cost-effective antibiotics.

Keywords: risk factors, adjunct treatment, ciprofloxacin, treatment outcome

\section{Introduction}

Epididymorchitis is the inflammation of the epididymis and testes. ${ }^{1}$ Usually, only the epididymis is affected. The testes become involved when the disease extends from the epididymis to the testes. It is classified as acute when the onset is sudden, and it is less than 6 weeks while the terms "subacute" or "chronic" are used when it lasted for more than 3 months ${ }^{2}$ Often, the inflammation follows ascending infection from the urethra, but may also be by direct inoculation or blood borne. ${ }^{3}$ 
Studies available indicate that acute epididymorchitis is uncommon. In 2002, epididymorchitis accounted for one in $144(0.69 \%)$ of clinic consultation in the USA in men between 18 and 50 years. ${ }^{4} \mathrm{~A}$ prospective study in Canada in 2004 demonstrated that $0.9 \%$ of men who attended the urology outpatient had epididymorchitis which was less common than prostatitis and interstitial cystitis. ${ }^{5}$ This places the disease in the mild-to-moderate category in terms of the burden on the Urologist and the Health Care system. The data on the epidemiology of the disease in Nigeria are scanty or unavailable, the closest to it being the work by Mbibu et al on acute scrotum. ${ }^{6}$ Though the disease may not be of public interest epidemiologically, it places a significant social and psychological burden on the affected men. Untreated or poorly treated, it may produce complications such as infertility ${ }^{4}$ with lifelong consequences. As a differential diagnosis of acute scrotum, it should be distinguished from testicular torsion.

Acute epididymorchitis is commonly an infective process that has the potential for occurring at any age. The offending pathogens vary with the age of the affected men and the underlying predisposing factors $(\mathrm{PF}){ }^{2}$ This to a large extent affects the mode of presentation, the severity of the disease, and the potential for further complications. Below the age of 35 years, Neisseria gonorrhoeae and Chlamydia trachomatis are usually the culprits. These pathogens are also the same as those isolated from the female partners of these men who have salpingitis and cervicitis. ${ }^{7}$ Above 35 years of age, Escherichia coli is the predominant pathogens though this is not absolute. This work was done in Irrua Specialist Teaching Hospital, a Federal tertiary institution located in rural Edo Central and subserving a population of approximately 4 million people. ${ }^{8}$ It was aimed at studying the common PF to acute epididymorchitis and the immediate (14 days) outcome of management in this predominantly rural community as there is paucity of data on the subject in this region.

\section{Materials and methods}

This is a retrospective study and ethical approval and patient consent were deemed not necessary. All the patients who were diagnosed in urology clinic, accident and emergency and the general outpatient as having epididymorchitis from January 2010 to December 2014 were included in the study. Males aged below 18 years and patients with testicular tumor with secondary inflammation were excluded. The predictor variables studied were age, duration between symptom onset and presentation (D1), symptom combination (Symptoms), the duration between commencement of treatment and clinical improvement (D2), organisms isolated (Pathogen), HIV status (HS), and treatment (TX) given. The others were need for adjunct treatment, PF, duration of hospital stay (D3), body mass index, complications, other comorbiditis, and number of sexual partners, while the outcome variables were the proportion of men whose disease resolved within 2 weeks of treatment (immediate outcome [IO]) and the correlation between the different variables. The diagnosis of underlying morbidities was based on history, physical examination, and investigation. For instance, in the diagnosis of bladder outlet obstruction (BOO), the presence of lower urinary tract symptoms, an abnormal digital rectal examination finding, and ultrasonographic finding of an enlarged prostate with or without bladder signs in the case of carcinoma of the prostate (CAP) and benign prostatic hyperplasia (BPH) were relied on. Suspected urethral stricture was subsequently confirmed with a retrograde urethrography. The information so obtained was analyzed using simple statistical methods and the statistical package for the social sciences (SPSS-17, SPSS Inc., Chicago, IL, USA).

\section{Results}

A total of 58 men who met the selection criteria were included in the study. Table 1 shows the age distribution of the patients. The risk factors included two (3.4\%) prostatitis, $36(62.1 \%) \mathrm{BOO}$, three (5.2\%) trauma/instrumentation, and ten $(17.2 \%)$ multiple sexual partners. No risk factor was found in seven (12.1\%). When age was cross tabulated with risk factors, there was a significant correlation $(P=0.000)$ but it had no statistically significant correlation with immediate management outcome ( $P=0.442$; Table 2).

The common modes of presentation were with fever, pain, and swelling in eleven (19\%), fever and pain in two (3.4\%), and swelling and pain in 45 (77.6\%). There was a significant correlation between the symptoms at presentation and IO of treatment using the Pearson's chi-square test $(P=0.000)$ and between the duration of these symptoms and management outcome $(P=0.000)$. The minimum duration of symptoms before presentation was 1 day, while the maximum was 28 days. The mean duration was 8.17 days (standard deviation $=6.45$ ).

Table I Age distribution of patients

\begin{tabular}{|c|c|c|c|c|c|}
\hline \multicolumn{2}{|c|}{ Age (years) } & \multirow{2}{*}{$\begin{array}{l}\text { Frequency } \\
\text { (n) } \\
4\end{array}$} & \multirow{2}{*}{$\begin{array}{l}\text { Percent } \\
6.9\end{array}$} & \multirow{2}{*}{$\begin{array}{l}\text { Valid } \\
\text { percent } \\
6.9\end{array}$} & \multirow{2}{*}{$\begin{array}{l}\begin{array}{l}\text { Cumulative } \\
\text { percent }\end{array} \\
6.9\end{array}$} \\
\hline Valid & $\leq 20$ & & & & \\
\hline & $21-40$ & 14 & 24.1 & 24.1 & 31.0 \\
\hline & $4 I-60$ & 19 & 32.8 & 32.8 & 63.8 \\
\hline & $>60$ & 21 & 36.2 & 36.2 & 100.0 \\
\hline & Total & 58 & 100.0 & 100.0 & \\
\hline
\end{tabular}


Table 2 Correlation between age and immediate outcome

\begin{tabular}{llll}
\hline Count & \multicolumn{2}{l}{} \\
\cline { 2 - 3 } Age (years) & Outcome $(\mathbf{n})$ & \multicolumn{1}{l}{ Total } \\
\cline { 2 - 3 } & Good & Poor & (N) \\
\hline$\leq 20$ & 3 & 1 & 4 \\
$21-40$ & 8 & 6 & 14 \\
$40-60$ & 12 & 7 & 19 \\
$>60$ & 17 & 4 & 21 \\
Total & 40 & 18 & 58 \\
\hline
\end{tabular}

Note: $P=0.442$.

The worst outcome was in patients who presented with pain and swelling without fever, while the best was in those with fever and scrotal pain only $(P=0.000)$. Of the 58 men, $43(74.2 \%)$ had no adjunct treatment, 13 (22.4\%) had a change from urethral catheter (Figure 1) to suprapubic diversion while two $(3.4 \%)$ had exploration for scrotal abscess. This adjunct treatment $(P=0.018)$ (Table 3$)$ and duration of symptoms before presentation $(P=0.000)$ had a statistically significant correlation with outcome. IO was considered good in $40(69 \%)$ and poor in $18(31 \%)$. Ciprofloxacin was the drug used in 57 (98.28\%) and cefuroxime in only one (1.72\%). The only patient for whom cefuroxime was used had a good IO. There was no statistically significant correlation between these drugs used and the treatment outcome.

The side affected (Table 4$)$ was not an independent factor in treatment outcome $(P=0.646)$ though it had a statistically significant correlation $(P=0.008)$ with the duration of symptoms before presentation (Table 5). Only one $(1.7 \%)$ patient who also had BOO, was HIV positive

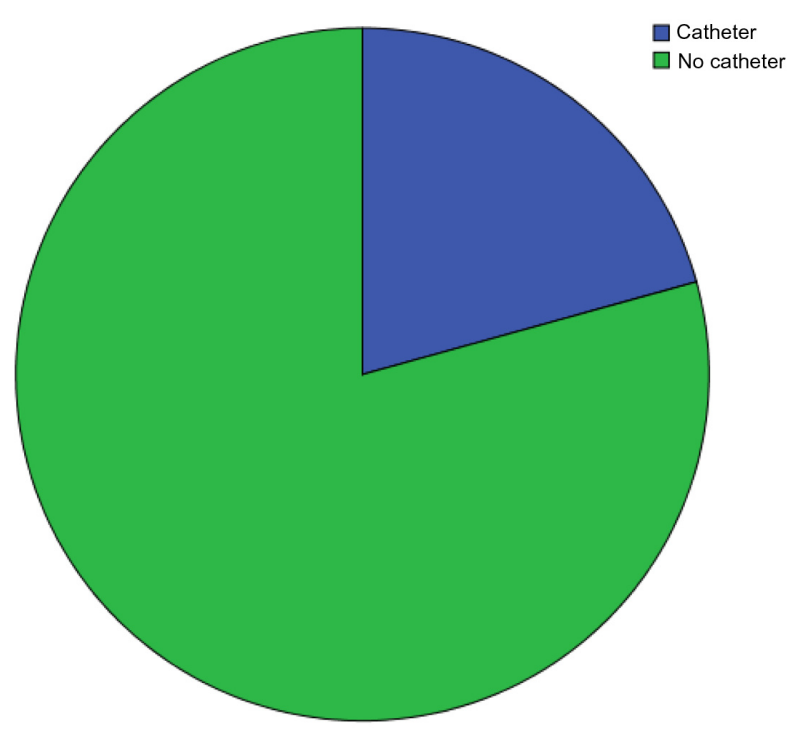

Figure I Urethral catheter status at presentation.
Table 3 Relationship between adjunct treatment and immediate outcome

\begin{tabular}{llll}
\hline Count & & \\
\hline Adjunct management & \multicolumn{2}{l}{ Outcome $(\mathbf{n})$} & Total \\
\cline { 2 - 3 } & Good & Poor & $(\mathbf{N})$ \\
\hline Exploration & 0 & 2 & 2 \\
Diversion & 12 & 1 & 13 \\
None & 28 & 15 & 43 \\
Total & 40 & 18 & 58 \\
\hline
\end{tabular}

Note: $P=0.018$.

indicating that this is not a strong independent risk factor for epididymorchitis.

Of the 35 men whose specimen (urethral swab/urine) culture and sensitivity results were available, the findings were: eight $(22.9 \%)$ E. coli, ten (28.5\%) Klebsiella, four (11.5\%) Enterobacter, one (2.8\%) Pseudomonas, two (5.7\%) other organisms, and ten $(28.6 \%)$ had no growth.

\section{Discussion}

Acute epididymorchitis is a urological emergency with varying degree of severity. In the USA, available data indicate that, 600,000 diagnosis of epididymorchitis is made annually. ${ }^{9}$ While the disease effect on the general population is low, complications such infertility ${ }^{10}$ abscess formation, ${ }^{11}$ and cosmetic deformation of the scrotum maybe enough to affect the quality of life of the affected men. According to De Schryver and Maheus, ${ }^{12}$ studies have shown persistent oligospermia in $40 \%$ of patients who had been treated for the disease. The presence of underlying predisposing disease may further lower the quality of life of these men as they maybe a cause of chronicity, loss of workdays, and subsequent socioeconomic ${ }^{12}$ and psychological disconnect. In our experience, the younger patients aged below 22 years are often brought for consultation by their parents, a situation with a potential for causing a family upset.

Many authors have documented two peak age incidences, the first being in the second decade and the second in the sixth decade of life. The second age peak was strongly confirmed by this study, but it was unable to establish the first peak age

Table 4 Frequency of involvement of each testis

\begin{tabular}{llllll}
\hline & $\begin{array}{l}\text { Affected } \\
\text { Side }\end{array}$ & $\begin{array}{l}\text { Frequency } \\
\text { (n) }\end{array}$ & Percent & $\begin{array}{l}\text { Valid } \\
\text { percent }\end{array}$ & $\begin{array}{l}\text { Cumulative } \\
\text { percent }\end{array}$ \\
\hline Valid & & I & 1.7 & 1.7 & 1.7 \\
& Right & 16 & 27.6 & 27.6 & 29.3 \\
& Left & 27 & 46.6 & 46.6 & 75.9 \\
& Bilateral & I4 & 24.1 & 24.1 & 100.0 \\
& Total & 58 & 100.0 & 100.0 & \\
\hline
\end{tabular}


Table 5 Duration of symptoms before presentation (Durl)

\begin{tabular}{clllll}
\hline Dur I & $\begin{array}{l}\text { Frequency } \\
\text { (n) }\end{array}$ & $\begin{array}{l}\text { Percent } \\
\text { Valid }\end{array}$ & $\begin{array}{l}\text { Valid } \\
\text { percent }\end{array}$ & $\begin{array}{l}\text { Cumulative } \\
\text { percent }\end{array}$ \\
6-10 days & 26 & 44.8 & 44.8 & 44.8 \\
II-15 days & 19 & 32.8 & 32.8 & 77.6 \\
> I5 days & 5 & 13.8 & 13.8 & 91.4 \\
Total & 58 & 8.6 & 8.6 & 100.0 \\
\hline
\end{tabular}

Note: $P=0.008$.

because of the noninclusion of pediatric patients. The first peak age of urinary tract infection (UTI) in men, according to Redshaw et al, ${ }^{13}$ is around the time of puberty. The risk factors for UTI and epididymorchitis in the younger age-group below 35 years are documented to include sexual activity, strenuous physical exercise, and bicycle or motorcycle riding. ${ }^{14}$ While this study overtly revealed that most men in this group had more than one sexual partner, it was unable to document the contribution of strenuous physical exercise, motorcycle and bicycle riding though motorcycle riding is common among men in this rural community. In older men, instrumentation, anatomic abnormalities, and recent urinary tract surgery are usually quoted as the risk factors for epididymorchitis and UTI. ${ }^{15}$ This study reflects this as $36(62.1 \%)$ of the 58 men had BOO either from CAP, BPH, or urethal stricture (Table 6). The age peak incidence coincided with that for BPH and CAP explaining the strongly significant statistical correlation $(P=0.000)$ between the risk factors in this study and the age of the patients (Table 7). The implication of this is that the diagnosis of epididymorchitis is incomplete in this group until the risk factor is identified or ruled out. The treatment of such risk factors will help in the prevention of recurrence or improve the response to care for the epididymorchitis.

Epididymorchitis is the most common cause of intrascrotal swelling, usually as a result of retrograde ascent of pathogens. In the acute disease, symptoms, which are usually present for

Table 6 The distribution of risk factors

\begin{tabular}{|c|c|c|c|c|c|}
\hline & $\begin{array}{l}\text { Predisposing } \\
\text { factors }\end{array}$ & $\begin{array}{l}\text { Frequency } \\
\text { (n) }\end{array}$ & Percent & $\begin{array}{l}\text { Valid } \\
\text { percent }\end{array}$ & $\begin{array}{l}\text { Cumulative } \\
\text { percent }\end{array}$ \\
\hline \multirow[t]{7}{*}{ Valid } & Prostatitis & 2 & 3.4 & 3.4 & 3.4 \\
\hline & BOO & 36 & 62.1 & 62.1 & 65.5 \\
\hline & Instrumentation/ & 3 & 5.2 & 5.2 & 70.7 \\
\hline & Trauma & & & & \\
\hline & $\begin{array}{l}\text { Multiple sex } \\
\text { partners }\end{array}$ & 10 & 17.2 & 17.2 & 87.9 \\
\hline & Nil & 7 & 12.1 & 12.1 & 100.0 \\
\hline & Total & 58 & 100.0 & 100.0 & \\
\hline
\end{tabular}

Note: $P=0.499$.

Abbreviation: $\mathrm{BOO}$, bladder outlet obstruction. less than 6 weeks, include fever, scrotal pain, and swelling. It may be left- or right-sided or involve both testes. While we were unable to relate this to the outcome of treatment, a statistically significant correlation $(P=0.008)$ existed between the affected side and duration of symptoms before presentation (Table 5). This is more likely to be related involving both testes as the longer the duration of symptoms, the more extensive the disease may become (Table 8). A mean duration of symptoms of 8 days before presentation implies that these men delayed in responding to their symptoms or have patronized intermediaries such as complementary and alternative medicine practitioners or general medical practitioners. The former abound in this rural community. Their activities are unregulated ${ }^{16}$ and it is not known how the later treat acute epididymorchitis in general practice. In Nigeria, and probably many of the sub-Saharan African countries, these men often patronize these intermediaries before presentation. ${ }^{6}$ This may account for why most of them presented with only scrotal pain and swelling, the attenuated form of the disease, as they may have been on treatment before presentation. This explains the statistically significant correlation $(P=0.000)$ between symptoms and outcome. It may also be that those without PF such as $\mathrm{BOO}$ resolved at the primary or secondary care level without reaching this tertiary care center. According to Nicholson et $\mathrm{al}^{17}$ in 2010 , it was not known how acute epididymorchitis was treated in the UK by general practitioners as guidelines for management were not followed.

The offending pathogen, to a large extent, depends on the age of the patient and the predisposing risk factor. In the younger age-group between 14 years and 35 years, $N$. gonorrhoeae and C. trachomatis are often responsible. In the older age-group, with the increasing presence of $\mathrm{BOO}$ as a risk factor, pathogens such as E. coli, Ureaplasma urealyticum, Proteus mirabilis, Klebsiella pneumoniae and Pseudomonas aeruginosa become responsible. ${ }^{18}$ This division is not absolute ${ }^{19}$ as it depends, to a large extent, on the sexual behaviors and permissiveness of the study population. ${ }^{20}$

The treatment of acute epididymorchitis consists of bed rest, scrotal elevation, and intravenous infusion where there is need and deployment of antibiotics. The initial choice of antibiotic is often empirical, ${ }^{4}$ while any subsequent change is based on the result of specimen culture and sensitivity. The symptoms and signs usually resolve within 2 weeks of effective treatment. This constitutes the basis for the stratification of IO in this work into good if this happens and poor if it took longer for resolution to occur. Independent factors, which influenced the immediate treatment outcome in this study, were duration of symptoms $(P=0.000)$, the symptoms 
Table 7 Relationship between age and predisposing factors

\begin{tabular}{|c|c|c|c|c|c|c|c|}
\hline \multicolumn{2}{|c|}{ Age distribution } & \multicolumn{5}{|c|}{ PF (n) } & \multirow{2}{*}{$\begin{array}{l}\text { Total } \\
\text { (N) }\end{array}$} \\
\hline & & BOO & Trauma/instrumentation & Prostatitis & MSP & Nil & \\
\hline \multirow[t]{5}{*}{ Age (years) } & $\leq 20$ & 0 & 2 & 1 & 0 & 1 & 4 \\
\hline & $21-40$ & 2 & I & 1 & 7 & 3 & 14 \\
\hline & $4 I-60$ & 11 & 1 & 1 & 1 & 2 & 16 \\
\hline & $>60$ & 23 & 0 & 0 & 0 & 1 & 24 \\
\hline & Total & 36 & 4 & 3 & 8 & 7 & 58 \\
\hline
\end{tabular}

Note: $P=0.000$.

Abbreviations: $\mathrm{BOO}$, bladder outlet obstruction; MSP, multiple sexual partners; PF, predisposing factors.

at presentation $(P=0.000)$, and the need for adjunct treatment $(P=0.018)$. The adjunct treatment included scrotal exploration, a change from urethral catheter to suprapubic urinary diversion and abscess drainage all of which are pointers to the need for a longer treatment period and hospital stay. The authors always find it useful to change from urethral catheter to suprapubic diversion after which it becomes easier to sterilize the urinary tract and prevent complications such as urethral stricture, chronicity, abscess formation, ${ }^{21}$ and infertility. These cofounders may have contributed to the IO.

\section{Conclusion}

The aim of treatment should be to prevent transmission and reduce future complications. In the younger age-group, Trojian et al ${ }^{4}$ recommend the use of ceftriaxone and azithromycin while in the elderly, ofloxacine. Like the UK experience, ${ }^{17}$ ofloxacines (though Ciprofoxacine) was the most commonly used antibiotic in this center during the study period and was deployed parenterally until there were signs of resolution. According to the UK guidelines of $2010,,^{22}$ in severely ill patients with features suggestive of bacteremia,

Table 8 Relationship between Durl and affected side

\begin{tabular}{|c|c|c|c|c|c|}
\hline \multirow{2}{*}{$\begin{array}{l}\text { Dur I } \\
\text { (days) }\end{array}$} & \multicolumn{4}{|l|}{ Side (n) } & \multirow{2}{*}{$\begin{array}{l}\text { Total } \\
\text { (N) }\end{array}$} \\
\hline & No record & Right & Left & Bilateral & \\
\hline 1.00 & 0 & 1 & 0 & 0 & 1 \\
\hline 2.00 & 0 & 0 & 2 & 1 & 3 \\
\hline 3.00 & 0 & 2 & 6 & 0 & 8 \\
\hline 4.00 & 0 & 1 & 4 & 0 & 5 \\
\hline 5.00 & 0 & 4 & 2 & 3 & 9 \\
\hline 6.00 & 1 & 0 & I & 0 & 2 \\
\hline 7.00 & 0 & 3 & 8 & 2 & 13 \\
\hline 8.00 & 0 & 0 & 0 & 1 & I \\
\hline 9.00 & 0 & I & 0 & 0 & I \\
\hline 10.00 & 0 & 1 & 0 & I & 2 \\
\hline 14.00 & 0 & 3 & 3 & 2 & 8 \\
\hline 21.00 & 0 & 0 & 0 & 2 & 2 \\
\hline 28.00 & 0 & 0 & I & 2 & 3 \\
\hline Total & I & 16 & 27 & 14 & 58 \\
\hline
\end{tabular}

Note: $P=0.008$.

Abbreviation: Durl, duration of symptoms before presentation. intravenous broad spectrum antibiotic directed at coliforms, and pseudomonas such as cefuroxime and ciprofloxacin should be used until fever subsides. Men treated in referral centers are likely to belong to this group. A common observation in our patients was though fever was absent on presentation, clinical examination usually revealed very ill patients which necessitated a $100 \%$ admission seen in this study. The use of ciprofloxacin in our practice was, however, mainly because of its cost and documented efficacy (because of the pKa of the prostate) in prostatitis which is often found in association with epididymorchitis. The Center for Disease Control (CDC) in its guidelines for the treatment of sexually transmitted infection, ${ }^{23}$ however, recommended the use of ceftriaxone or fluoroquinolone (in addition to doxycycline) in those who practice anal insertive intercourse and ofloxacine or levofloxacine in suspected enteric pathogens. The only patient (also had a scrotal ulcer) for whom cefuroxime was used in this study had a good outcome and in view of the just above average IO in this study $(69 \%)$, there is a need for prospective studies to document the effects of cofounders and what the appropriate antibiotics are to improve the immediate (14 days) outcome. This will in turn help in the establishment of management guidelines.

\section{Disclosure}

The authors report no conflicts of interest in this work.

\section{References}

1. Banyra O, Shulyak A. Acute epididymo-orchitis: staging and treatment. Cent European J Urol. 2012;65(3):139-143. doi 10.5173/ceju.2012.03.art8.

2. Walker NA, Challacombe B. Managing epididymo-orchitis in general practice. Practioner. 2013;257(1760):21-25.

3. Ochsendorf FR. Sexually transmitted infections: impact on male fertility. Andrologia. 2008;40(2):72-75. doi 10.1111/j.14390272.2007.00825.x.

4. Trojian TH, Lishnak TS, Heiman D. Epididymitis and orchitis: an overview. Am Fam Physician. 2009;79(7):583-587.

5. Chi S, Fakete T. Epididymorchitis. In: Schlossberg D, editor. Clinical Infectious Disease. 2nd ed. Cambridge: Cambridge University Press; 2015:401-405.

6. Mbibu NH, Maitama HY, Ameh EA, Khalid IM, Adams LM. Acute Scrotum in Nigeria: an 18-year review. Trop Doct. 2004;34(1):34-36. 
7. Berbear C, de Barbeyrac B. Genital Chlamydia trachomatis infection. Clin Microbiol Infect. 2009;15(1):4-10. doi 10.1111/j.1469-0691.2008. 02647.x.

8. Dongo AE, Irekpita EE, Osaghele LO, Ogbebor CE, Iyamo CE, Onunminya JE. A five year review of burns injury in Irrua. BMC Health Serv Res. 2007;7:171. doi 10.1186/1471-6963-7-171.

9. National Center for Health Statistics. National Ambulatory Medical Care Survey; 2002 Available from: http://www.cdc.gov/nchs/about/ major/ahcd/ahcd1.htm. Accessed November 3, 2015.

10. Paavonen J, Eggert-Kruse W. Chlamydia trachomatis: impact on human reproduction. Hum Reprod Update. 1999;5(5):433-447.

11. Kashiwagi B, Okugi H, Morita T, KatoY, Shabita Y, Yamamaka H. Acute epididymorchitis with abscess formation due to Pseudomonas aeruginosa. Report of three cases. Hinyokika Kiyo. 2000;46(12): 915-918.

12. De Schryver A, Maheus A. Epidemiology of sexually transmitted diseases; the global picture. Bull World Health Organ. 1990;68(5):639-654.

13. Redshaw JD, Tran TL, Wallis MC, deVries CR. Epididymitis: a 21-year retrospective review of presentation to an out patient urology clinic. J Urol. 2014;192(4):1203-1207. doi 10.1016/j.jurol 2014.04.002.

14. Kadish HA, Bolte RG. A retrospective study of pediatric patients with epididymitis, testicular torsion and torsion of testicular appendages. Pediatrics. 1998;102(1 pt 1):73-76.
15. Luzzi GA, O’ Brien TS. Acute epididymorchitis BJU Int. 2001;87(8): $747-755$.

16. Aghaji AE. Fournier's gangrene. Niger J Surg Sci. 2000;10:7-11.

17. Nicholson A, Rait G, Murray-Thomas T, Hughes G, Mercer CH, Cassell G. Management of epididymo-orchitis in primary care: results from a large UK primary care database. Br J Gen Pract. 2010; 60(579):e407-e422. doi 10.3399/bjgp/ox532413.

18. Manavi K, Turner K, Scoft GR, Stewart LH. Audit of the management of epididymorchitis by the Department of Urology in Edinburgh. Int J STD AIDS. 2005;16(5):386-387.

19. Lee CT, ThirumoorthyT, Lim KB, Sng EH. Epidemiology of acute epididymo-orchitis in Singapore. Ann Acad Med Singapore. 1989; 18(3):320-323.

20. Street EJ, Portman MD, Kopa Z, et al. European Guideline on the Management of Epididymorchitis. Parramatta, NSW: IUSTI; 2012.

21. Machida H, Ueno E, Nakazawa H, Fujimura M, Ito F. Spermatic cord abscess with concurrent prostatic abscess involving the seminal vesicles. Radiat. Med. 2008;26(2):81-83. doi:10.1007/511604-007-0193.

22. Street E, Joyce A, Wilson J. 2010 United Kingdom National Guide line for the management of epididymorchitis.

23. Division of STD Prevention. National Center for HIV/AIDS, Viral Hepatitis, STD and TB prevention. 2010 STD Treatment Guide Line. Available from: http://www.cdc.gov/std/treatment. Accessed November 2, 2015.
Clinical Audit

\section{Publish your work in this journal}

Clinical Audit is an international, peer-reviewed, open access journal focusing on the processes and outcomes of clinical audit in any area of healthcare. All aspects of patient care are addressed within the journal and practitioners from all disciplines are invited to submit their work. Areas covered include: Publication of audits; How an audit has changed practice;

Submit your manuscript here: http://www.dovepress.com/clinical-audit-journal

\section{Dovepress}

Practical tips on how to do audits and to avoid pitfalls; How audits have changed patient care; Calls and justifications for new audits. The manuscript management system is completely online and includes a very quick and fair peer-review system, which is all easy to use. Visit http://www.dovepress. com/testimonials.php to read real quotes from published authors. 